\title{
REVIEW
}

\section{Prognostic factors in lung cancer: Tables and Comments}

\author{
G. Buccheri, D. Ferrigno
}

\begin{abstract}
Prognostic factors in lung cancer: Tables and Comments. G. Buccheri, D. Ferrigno. CERS Journals Ltd 1994.

ABSTRACT: Prognostic factors (PF) have a pivotal role in Clinical Oncology. They are helpful in the selection of treatment, provide insights into the disease process and the therapeutic response, and are fundamental in the design of clinical trials or in the interpretation of data from the literature. The number of possibly useful PFs in lung cancer is large (certainly more than one hundred). This paper attempts to provide a comprehensive listing of PFs and other variables potentially associated with outcome of lung cancer. This is achieved using tables, where studies relevant to each $P F$ are referenced in relationship to their results, statistical power, type of analysis, number of variables incorporated in multivariate tests, and cell type. Tables include the outcome of an extensive retrieval of the literature and indicate visually where much of the evidence resides for the contribution of a variable to prognosis. Each table is briefly discussed and systematically comprises one group of PFs.

Among the many pinpointed, the best predictive models still belong to studies based on clinical and routine laboratory data. Recent researches have clarified the role of new PFs (such as the biological factors); others (e.g. quality of life measures, the serum content of acute phase reaction proteins or the pathological evidence of tumour neoangiogenesis) might be recognized as important in the future. Like infinity, the fate of the individual patient will never become a completely measurable entity. However, as the discovery of new PFs proceeds, the assessment of the future prospects for patients is becoming more reliable.
\end{abstract}

Eur Respir J., 1994, 7, 1350-1364.

A. Carle Hospital of Chest Diseases, Cuneo, Italy.

Correspondence: G. Buccheri

via Repubblica 10/c

I-12018 Roccavione $(\mathrm{CN})$, Italy

Keywords: Non-small-cell lung cancer prognostic factors

small-cell lung cancer

Received: 13 September 1993

Accepted after revision March 271994
The recognition of prognostic factors (PFs) in lung cancer (LC) has several aims including the following: 1. individual prognostic counselling; 2 . selecting treatment -when therapeutic options depend on the baseline clinical characteristics of the subject-; 3 . adjusting for inhomogeneities in comparing groups of patients from different locations and studies; 4. defining the eligibility criteria for new clinical trials and stratifying patients by risk subgroups; 5 . understanding - certain factors may provide insights into the disease process and provide direction for further studies.

Although some of these reasons may appear rather theoretical, they do have practical relevance. As for many other solid tumours, the variability in prognosis among LC patients is more substantial than improvements in prognosis due to therapy [1], and the failure to appreciate the importance of PFs adequately may contribute to the design of inefficient studies, the erroneous interpretation of results, and the development of inconsistent literature.

Traditionally, a number of baseline clinical characteristics have been used to predict the outcome of patients with LC [1-6]. More recently, simple biochemical tests were thought to be part of the minimal "core" set of important factors [7-9]. At present, newer tests, mostly based on the experimental evidence arising in the lab- oratory at the cellular and molecular level [10], are being proposed. Unfortunately, the interpretation of relevant literature is not easy. Apart from the magnitude of such literature, there is a remarkable inhomogeneity among studies. Major differences concern:

1. Study populations - patients may be considered if they have lung cancer of any cell type, resected nonsmall cell lung cancer (NSCLC), inoperable NSCLC, or a tumour of a specific cell type, either surgically or nonsurgically treated;

2. Diagnostic criteria and treatment modalities;

3. Statistical analysis (e.g., univariate log-rank test, Kaplan-Meyer and Breslow-Gehan statistics, or multivariate Cox' logistic regression and recursive partitioning and amalgamation algorithms (RPPA). A number of recent papers have discussed these methods in detail [11-13]);

4. The mix of variables which are taken into consideration (a very important source of variability, since the selection of significant covariates in multivariate models depends mainly on what is being tested);

5. The inclusion of post-treatment factors such as response to treatment. These factors need specific corrections, including the landmark and transient state analyses [5], which have not always been performed; 
Table 1. - Tumour biology characteristics*

\begin{tabular}{|c|c|c|c|c|c|c|c|c|}
\hline & \multicolumn{4}{|c|}{ Nonsignificant** } & \multicolumn{4}{|c|}{ Significant** } \\
\hline & \multicolumn{2}{|c|}{ Univariate analysis } & \multicolumn{2}{|c|}{ Multivariate analysis } & \multicolumn{2}{|c|}{ Univariate analysis } & \multicolumn{2}{|c|}{ Multivariate analysis } \\
\hline & $>200 \mathrm{pts}$ & $\leq 200 \mathrm{pts}$ & $\begin{array}{l}>200 \mathrm{pts} \\
\text { and/or } \leq 6 \\
\text { variables }\end{array}$ & $\begin{array}{c}\leq 200 \mathrm{pts} \\
\text { and }>6 \\
\text { variables }\end{array}$ & $\leq 200 \mathrm{pts}$ & $>200 \mathrm{pts}$ & $\begin{array}{l}\leq 200 \mathrm{pts} \\
\text { and/or } \leq 6 \\
\text { variables }\end{array}$ & $\begin{array}{c}>200 \mathrm{pts} \\
\text { and }>6 \\
\text { variables }\end{array}$ \\
\hline $\begin{array}{l}\text { Neural cells adhesion } \\
\text { molecule }\end{array}$ & & & & & & {$[14]$} & & \\
\hline Neuronendocrine features & & & & & [15] (16) & & & \\
\hline Oncogene abnormalities & & & & & {$[17-20]$} & {$[21]$} & {$[18]$} & \\
\hline Oncogene products & & {$[22]$} & & & [23] & & [23] & \\
\hline $\begin{array}{l}\text { Growth factors and their } \\
\text { receptors }\end{array}$ & & & & & {$[24,25]$} & & & \\
\hline $\begin{array}{l}\text { Blood-group antigen } \\
\text { expression }\end{array}$ & & & & & {$[26]$} & & [26] & \\
\hline Thymidine labelling index & & [27] & & & [28] & & {$[27,28]$} & \\
\hline Flow cytometry & & & & & $\begin{array}{l}{[29-40]} \\
(41-43)\end{array}$ & [44] & $\begin{array}{l}{[30,32-34} \\
36,38,40]\end{array}$ & \\
\hline $\begin{array}{l}\text { Cell line establishment } \\
\text { in vitro }\end{array}$ & & & & & $\begin{array}{l}{[45,46]} \\
(47,48)\end{array}$ & & $\begin{array}{c}{[45]} \\
(47,48)\end{array}$ & \\
\hline
\end{tabular}

For explanation of table layout see text below. * Reference numbers in square brackets refer to studies of [NSCLC/any cell type tumours], numbers in parentheses refer to studies of (pure SCLCs). ** according to definitions in the various studies. NSCLC: non-small cell lung carcinoma; SCLC: small cell lung carcinoma.

6. The end-points themselves (e.g., the entire survival curve or survival at particular times, usually survival rates at 5 to $10 \mathrm{yrs}$ ).

With such an abundance and heterogeneity of data, how can a physician determine which pretreatment test, or group of tests, best predicts an adverse outcome? So far, two approaches have been followed. The first is constituted by the classic review, in which the author intending to review a topic describes, comments on, and criticizes a selection of original papers. Accepted limits to this approach are the subjectivity of each of the above mentioned passages, and the absence of quantitative evaluations. The alternative approach is to try to have a quantitative estimate of the performance of each variable. A meta-analysis study of the risk-ratios for mortality, found in populations with different expression of a particular prognostic factor, could be the appropriate method for this quantitative evaluation. This means, however, a new investigation for each PF, with the persistent problem of integrating information from various studies.

This paper intends to use an intermediate approach, between the merely qualitative method of the classic review and the quantitative estimation of meta-analysis. It is based on a systematic overview of the results of quite a large number of original studies, presented in nine tables and briefly commented on. Practically, the studies relevant to each PF are referenced in relationship to their result (significant or nonsignificant, according to the authors' definitions), statistical power (including up to 200 patients or more), type of analysis (univariate and/or multivariate), number of variables incorporated in multivariate tests (up to 6 or more), and cell type (small cell lung cancer (SCLC) only or NSCLC and mixed histologies).
In order to provide an immediate appreciation of the importance of each PF, references are ordered in columns, located from the left to the right side in correlation with the strength of positiveness of their findings. A right crowding of references indicates an important prognostic factor, while the left locations mean a negligible one. The end-point used for study selection was overall survival; while particular survival rates, such as rates at 5 or 10 years, were not considered. In the same way, treatment and post-treatment variables were not considered. However, since post-treatment factors may influence results, their possible inclusion in multivariate models has been noted.

\section{Tumour biology characteristics (table 1)}

The biological characteristics of tumours, which have been shown to possess some prognostic relevance in lung cancer, include neuronal and neuroendocrine features, oncogene abnormalities and their products, growth factors and their receptors, blood-group antigen expression, thymidine labelling index, deoxyribonucleic acid (DNA) content and fraction of S,G2,M-phase tumour cells, and, finally, their ability to obtain and expand in vitro cell lines from tumour specimens. Table 1 provides the relevant references. Common characteristics of this group of PFs are their recent or very recent discovery, the relatively small size of studies (only three series had more than 200 patients), the absence of multivariate analyses with large sets of cofactors (which means difficulty in the judgement of their relative value), the near absence of negative studies (which makes these PFs quite interesting and worthy of further evaluation), and scarce 
representation of studies specialized in SCLCs. The main difference among the factors lies in the degree of complexity of their determination (oncogenes, for example, can be studied only in well equipped laboratories). Another difference lies in the degree of supporting evidence, which is very high for DNA measurements, but more often needs further evaluation.

In the past, DNA content in tumour cells was measured by a variety of techniques, the most widespread of them being the static cytophotometry [49]. The introduction of flow cytometry has permitted the rapid and quantitative determination of diverse individual cellular characteristics, including the abnormalities in DNA and growth kinetic. Since 1985, at least 16 studies, which in total include more than 1,500 patients, have clearly demonstrated the important correlation existing between DNA content and LC survival probability (table 1). This correlation persisted when a few other strong survival predictors (generally, extent of disease and performance status) were taken into consideration. However, because of the necessity of obtaining large samples of tumour, more than $90 \%$ of the total evidence is due to resected NSCLCs. This implies that the prognostic significance of DNA patterns in advanced NSCLC and in SCLC is not yet definitively ascertained.

Oncogene-related anomalies comprise a heterogeneous group including abnormalities of c-ras-HA, c-myb, cmyc, 1-myc, c-raf-1 genes in NSCLC [17, 19, 21], and, in adenocarcinomas, p185(neu) protein expression of HER2/neu protooncogene [23], K-ras activation [18], and ras family mutation [43]. Based on the available data, it is quite clear that the presence of gene anomalies is well correlated with the survival duration of NSCLC patients.
Their value, however, remains more speculative than practical. Similar considerations apply to the ability of establishing cell lines in vitro, a prognostic factor which has proved equally important in NSCLCs and SCLCs [45-48]. As previously stated, convincing evidence for other biological characteristics is generally scarce.

\section{Histopathology (table 2)}

The attempt to correlate simple morphological aspects of malignant cells and tissues with the biological behaviour of the tumour and its clinical course is of practical interest as it has had scant result so far. Histopathological features, claimed to be potentially effective, include tumour cell types and subtypes (as defined by the World Health Organisation (WHO) [50]), grading of histological differentiation and ultrastructural differentiation, histological heterogeneity, tumour neovascularization, and peritumour lymphoid infiltration. References for these histopathology factors are listed in table 2. The common feature of this group is the inconsistency of results, as demonstrated by the roughly equal number of studies, where significant differences in prognosis of tumours with different histopathological patterns were found. Unlike any other factor of this group, the prognostic significance of the major cell types has been assessed through many studies, most of which account for multiple cofactors (table 2).

In NSCLC resected for cure, squamous cell carcinoma should do consistently better than adenocarcinoma and large cell carcinoma [1]. However, in some studies, adenocarcinomas did better than any other histotype [64-68], and in others no difference was observed [52]. Similar

Table 2. - Histopathologic aspects*

\begin{tabular}{|c|c|c|c|c|c|c|c|c|}
\hline & \multicolumn{4}{|c|}{ Nonsignificant** } & \multicolumn{4}{|c|}{ Significant** } \\
\hline & \multicolumn{2}{|c|}{ Univariate analysis } & \multicolumn{2}{|c|}{ Multivariate analysis } & \multicolumn{2}{|c|}{ Univariate analysis } & \multicolumn{2}{|c|}{ Multivariate analysis } \\
\hline & $>200 \mathrm{pts}$ & $\leq 200 \mathrm{pts}$ & $\begin{array}{l}>200 \mathrm{pts} \\
\text { and/or } \leq 6 \\
\text { variables }\end{array}$ & $\begin{array}{c}\leq 200 \mathrm{pts} \\
\text { and }>6 \\
\text { variables }\end{array}$ & $\leq 200 \mathrm{pts}$ & $>200 \mathrm{pts}$ & $\begin{array}{l}\leq 200 \mathrm{pts} \\
\text { and/or } \leq 6 \\
\text { variables }\end{array}$ & $\begin{array}{c}>200 \mathrm{pts} \\
\text { and }>6 \\
\text { variables }\end{array}$ \\
\hline Major cell types & [51-55] & {$[56-59]$} & $\begin{array}{l}{[30,51,52,} \\
55,60-63]\end{array}$ & [56-59] & $\begin{array}{l}{[27,30,} \\
64,65]\end{array}$ & {$[60,66-73]$} & {$[27,65,68]$} & {$[69,70,72]$} \\
\hline Adenosquamous cell type & & & & & [74] & & [74] & \\
\hline SCLC subtyping & $(75-77)$ & (78) & & & $(79,80)$ & $(81)$ & & \\
\hline $\begin{array}{l}\text { Adenocarcinoma } \\
\text { subtyping }\end{array}$ & {$[82]$} & & {$[82]$} & & & [83] & {$[84]$} & \\
\hline $\begin{array}{l}\text { Ultrastructural LC } \\
\text { differentiation }\end{array}$ & & {$[85]$} & & & & & & \\
\hline $\begin{array}{l}\text { Ultrastructural BA } \\
\text { differentiation }\end{array}$ & & {$[86]$} & & & & & & \\
\hline Histologic heterogeneity & & & [62] & & & & & \\
\hline $\begin{array}{l}\text { Peritumour lymphoid } \\
\text { infiltration }\end{array}$ & & & & & [87] & & [87] & \\
\hline Tumour neovascularization & & & & & {$[88]$} & & [88] & \\
\hline $\begin{array}{l}\text { Tumour grading of } \\
\text { differentiation }\end{array}$ & {$[82,89]$} & {$[90]$} & {$[82,89]$} & {$[90]$} & & [91] & [91] & \\
\hline
\end{tabular}


Table 3. - Paraneoplastic syndromes*

\begin{tabular}{|c|c|c|c|c|c|c|c|c|}
\hline & \multicolumn{4}{|c|}{ Nonsignificant** } & \multicolumn{4}{|c|}{ Significant** } \\
\hline & \multicolumn{2}{|c|}{ Univariate analysis } & \multicolumn{2}{|c|}{ Multivariate analysis } & \multicolumn{2}{|c|}{ Univariate analysis } & \multicolumn{2}{|c|}{ Multivariate analysis } \\
\hline & $>200 \mathrm{pts}$ & $\leq 200 \mathrm{pts}$ & $\begin{array}{c}>200 \mathrm{pts} \\
\text { and/or } \leq 6 \\
\text { variables }\end{array}$ & $\begin{array}{c}\leq 200 \mathrm{pts} \\
\text { and }>6 \\
\text { variables }\end{array}$ & $\leq 200 \mathrm{pts}$ & $>200 \mathrm{pts}$ & $\begin{array}{c}\leq 200 \mathrm{pts} \\
\text { and/or } \leq 6 \\
\text { variables }\end{array}$ & $\begin{array}{c}>200 \mathrm{pts} \\
\text { and }>6 \\
\text { variables }\end{array}$ \\
\hline SIADH & (94) & & (94) & & & & & \\
\hline Overall & {$[52,72]$} & & {$[52,72]$} & & $(95,96)$ & & (96) & \\
\hline Clubbing & [69] & & [69] & & & & & \\
\hline Cushing's syndrome & & & & & (97) & & & \\
\hline
\end{tabular}

* Reference numbers in square brackets refer to studies of [NSCLC/any cell type tumours]; numbers in parentheses refer to studies of (pure SCLCs) ** according to definitions in the various studies. SIADH: inappropriate secretion of antidiuretic hormone. For further definitions see legend to table 1.

inconsistencies can be observed in advanced NSCLCs (table 2). Thus, if the different non-small cell histologies have some prognostic impact, this would be rather modest.

In 1988, the Pathology Committee of the International Association for the Study of Lung Cancer recommended abandoning the WHO subclassification of SCLC [50], and adopting the three new subtypes of small cell, mixed small/large cell, and combined small cell carcinomas [92] This proposal was an attempt to make the subtypes of SCLC more relevant clinically. Prior studies had shown that mixed small/large cell cancers could be associated with worse prognoses than pure SCLCs $[79,81]$. But, again, any clinical relevance of the morphological approach was rejected by two following larger studies [76, 77].

As far as the remaining histopathological aspects are concerned, the data are negative or insufficient. However, the lymphoid peritumour infiltration, measured morphometrically in randomized microscopic fields from 30
NSCLC [87], and the tumour neoangiogenesis, measured by the number and density of tumour microvessels from 87 T1N0M0 resected NSCLCs [88], are stimulating possibilities for further pathological research. Indeed, the growth of a tumour beyond a certain size requires angiogenesis [93].

\section{Paraneoplastic syndromes (table 3)}

It is stimulating to contemplate the fact that tumours manifesting paraneoplastic syndromes may be associated with worse clinical outcomes. The possibility of a different outcome has been verified at least for the following syndromes: inappropriate secretion of antidiuretic hormone (SIADH); Cushing's syndrome; digital clubbing; and all the paraneoplastic syndromes together. Appropriate references are given in table 3. As shown,

Table 4. - Immune factors*

\begin{tabular}{|c|c|c|c|c|c|c|c|c|}
\hline & \multicolumn{4}{|c|}{ Nonsignificant ${ }^{* *}$} & \multicolumn{4}{|c|}{ Significant** } \\
\hline & \multicolumn{2}{|c|}{ Univariate analysis } & \multicolumn{2}{|c|}{ Multivariate analysis } & \multicolumn{2}{|c|}{ Univariate analysis } & \multicolumn{2}{|c|}{ Multivariate analysis } \\
\hline & $>200 \mathrm{pts}$ & $\leq 200 \mathrm{pts}$ & $\begin{array}{l}>200 \mathrm{pts} \\
\text { and/or } \leq 6 \\
\text { variables }\end{array}$ & $\begin{array}{c}\leq 200 \mathrm{pts} \\
\text { and }>6 \\
\text { variables }\end{array}$ & $\leq 200 \mathrm{pts}$ & $>200 \mathrm{pts}$ & $\begin{array}{c}\leq 200 \mathrm{pts} \\
\text { and/or } \leq 6 \\
\text { variables }\end{array}$ & $\begin{array}{c}>200 \mathrm{pts} \\
\text { and }>6 \\
\text { variables }\end{array}$ \\
\hline $\begin{array}{l}\text { Delayed skin } \\
\text { hypersensitivity }\end{array}$ & {$[52,69,72]$} & [98] & {$[52,69,72]$} & & (99) & & (99) & \\
\hline Interleukin-2 & & & & & {$[100]$} & & & \\
\hline $\begin{array}{l}\text { Soluble interleukin-2 } \\
\text { receptors }\end{array}$ & & & & & [101] & & & \\
\hline $\begin{array}{l}\text { Lymphocyte tumour- } \\
\text { killing activity }\end{array}$ & & & & & [102] & & & \\
\hline Serum amyloid A protein & & & & & {$[103]$} & & & \\
\hline Concanavalin A response & & & & & [103] & & & \\
\hline $\begin{array}{l}\text { 3rd component of } \\
\text { complement }\end{array}$ & & {$[65]$} & {$[70]$} & {$[65]$} & & {$[70]$} & & \\
\hline Immunoglobulins & {$[70,104]$} & & {$[70,104]$} & {$[65]$} & {$[65]$} & & & \\
\hline Immunocomplexes & & & & {$[65]$} & {$[65]$} & & & \\
\hline
\end{tabular}

* Reference numbers in square brackets refer to studies of [NSCLC/any cell type tumours]; numbers in parentheses refer to (pure SCLCs) $* *$ according to definitions in the various studies. For further definitions see legend to table 1 . 
the data are scanty, probably because of the comparative rarity of this type of clinical manifestation, and more often negative. According to a British study on 337 operated patients [69], clubbing is not an important PF in NSCLC. Likewise, SIADH did not influence the overall survival of 350 patients with SCLC [94]. On the contrary, a very recent study at the MD Anderson Cancer Centre, comparing 11 SCLC patients with paraneoplastic Cushing's syndrome, who died within 90 days of the initial administration of chemotherapy, and 90 fully comparable control subjects, concluded that the syndrome did have adverse prognostic significance [97]. Inconsistent results were obtained when the survival of patients with no paraneoplastic syndrome was compared with the survival of patients who manifested syndromes of any type (table 3).

\section{Immune factors (table 4)}

It is well-known that host immune response plays a critical role in defending the organism against tumour cells. Various immune factors can predict the clinical outcome of LC, including: delayed skin hypersensitivity testing; serum concentration of interleukin- 2 and its soluble receptors; serum concentration of the amyloid A protein; 3rd component of the complement (C3), immunoglobulins, and immunocomplexes; lymphocyte tumourkilling activity, and response to Concanavalin A. Table 4 summarizes the results of studies, in which the above factors were evaluated.
Delayed cutaneous hypersensitivity is the simplest and the most common way of evaluating cellular immunocompetence. It has been exploited throughout the last 2 or 3 decades, as it was anecdotally believed to be a possible PF. However, the most recent and internationally widespread evidence appears rather negative in this regard, at least for surgically treated NSCLCs [52, 69, 72, 98]. The only positive experience comes from the NCI-VA Medical Oncology Branch, which in 1983 tested prospectively 154 SCLC patients with the following 5 antigens: purified protein derivative (PPD), mumps, candida, streptokines/streptodornase, and histoplasmin [99].

Other negative findings concern the serum concentration of immunoglobulins, immunocomplexes, and $\mathrm{C} 3$. Data on the remaining factors are quite sporadic and need confirmation (table 4).

\section{Tumour markers (table 5)}

This chapter comprises many different substances, from the hormones of historical significance to the continuously growing family of tumour-associated antigens.

In addition to prognostication, tumour markers can be helpful in screening and early diagnosis of cancer, in the initial assessment of the extent of the disease, and in monitoring tumour growth (or tumour reduction), once the diagnosis of cancer has been established and the treatment started [105]. Tumour markers have been measured in any body fluid and, immunohistochemically, in

Table 5. - Tumour markers*

\begin{tabular}{|c|c|c|c|c|c|c|c|c|}
\hline & \multicolumn{4}{|c|}{ Nonsignificant** } & \multicolumn{4}{|c|}{ Significant** } \\
\hline & \multicolumn{2}{|c|}{ Univariate analysis } & \multicolumn{2}{|c|}{ Multivariate analysis } & \multicolumn{2}{|c|}{ Univariate analysis } & \multicolumn{2}{|c|}{ Multivariate analysis } \\
\hline & $>200 \mathrm{pts}$ & $\leq 200 \mathrm{pts}$ & $\begin{array}{l}>200 \mathrm{pts} \\
\text { and/or } \leq 6 \\
\text { variables }\end{array}$ & $\begin{array}{c}\leq 200 \mathrm{pts} \\
\text { and }>6 \\
\text { variables }\end{array}$ & $\leq 200 \mathrm{pts}$ & $>200 \mathrm{pts}$ & $\begin{array}{l}\leq 200 \mathrm{pts} \\
\text { and/or } \leq 6 \\
\text { variables }\end{array}$ & $\begin{array}{c}>200 \mathrm{pts} \\
\text { and }>6 \\
\text { variables }\end{array}$ \\
\hline $\begin{array}{l}\text { Carcinoembryonic } \\
\text { antigen }\end{array}$ & {$[70,72]$} & $\begin{array}{c}{[65,90,} \\
106] \\
(96,107)\end{array}$ & $\begin{array}{c}{[70,72} \\
89,108] \\
(109)\end{array}$ & $\begin{array}{c}{[57,65,} \\
90] \\
(96,110)\end{array}$ & $\begin{array}{c}{[57,108} \\
111-114] \\
(110,115-118)\end{array}$ & $\begin{array}{c}{[89,119,} \\
120] \\
(109)\end{array}$ & $(116,117)$ & \\
\hline Neuron specific enolase & & (121) & & (110) & $\begin{array}{c}(107,110,115, \\
122-125)\end{array}$ & & (122) & \\
\hline $\begin{array}{l}\text { Tissue polypeptide } \\
\text { antigen }\end{array}$ & & (107) & & [57] & $\begin{array}{l}{[57,106,111][} \\
\quad(110)\end{array}$ & $61,89,126]$ & $(110,121)$ & {$[61,89]$} \\
\hline Squamous cell antigen & [119] & & & & & {$[127]$} & & \\
\hline Creatine kinase $\mathrm{BB}$ & & & & & (115) & & & \\
\hline Thimidine kinase & & & & (110) & $(110,118)$ & & $(121)$ & \\
\hline CA $19-9$ & & [106] & & & & & & \\
\hline CA 125 & & & & & {$[128,129]$} & & & \\
\hline ACTH & & {$[65]$} & & & & & {$[65]$} & \\
\hline HCG & & [111] & & & {$[65]$} & & {$[65]$} & \\
\hline Calcitonin & [72] & [65] & [72] & & & & {$[65]$} & \\
\hline Alpha-fetoprotein & & & & & {$[65]$} & & {$[65]$} & \\
\hline
\end{tabular}

* Reference numbers in square brackets refer to studies of [NSCLC/any cell type tumours]; numbers in parentheses refer to (pure SCLCs) ** according to definitions in the various studies. CA: carcinoantigen; ACTH: adrenocorticotropin hormone; HCG: human chorionic gonadotropic hormone. For further definitions see legend to table 1 . 
tumour tissues [105]. The attention, however, is usually centred on pre-treatment serum measurements, as they are the most common source of clinical information. Table 5 provides summarizing data on carcinoembryonic antigen (CEA), neuron specific enolase (NSE), tissue polypeptide antigen (TPA), squamous cell carcinoma antigen (SCCA), antigens CA19-9 and CA125, thymidine kinase, creatine kinase isoenzyme BB (CPK$\mathrm{BB})$, adrenocorticotropin hormone (ACTH), beta-subunit of the chorionic gonadotropic hormone (b-HCG), calcitonin, and alpha-fetoprotein. As a group, tumour markers share no common characteristic. There is a large diversity of supporting evidence and possible conclusions. At least one of these substances, the TPA, shows features of the ideal PF (effectiveness, simplicity, independence from other PFs).

Six out of 8 SCLC and 9 out of 14 NSCLC studies have proved that CEA possesses some prognostic relevance. This prognostic significance appears either: certain (thousands of patients and six large studies provide information on the antigen), rather weak (not confirmed in any study with great statistical power), slightly weaker in NSCLC than in SCLC (more negative studies in the first group), and hardly independent (no statistical significance within multivariate analyses containing more than six factors).

In SCLC, a great many studies suggest that NSE is an effective prognostic indicator, on its own; but data on its possible independence from the other PFs are few and rather inconsistent (table 5).

TPA seems to be effective in any cell type of LC.
Eight studies with several hundred patients have clearly shown that this marker is well correlated with the prognosis of LC, and this correlation persists when numerous other PFs are taken into account. However, it is necessary to wait for other studies, for the simple reason that most of the evidence was provided by a single research group (table 5).

Preliminary data would suggest that thymidine kinase in SCLC and CA 125 in NSCLC might be useful, while results concerning hormones and other markers are negative or absolutely inconsistent (table 5).

\section{Other uncommon laboratory tests (table 6)}

There is a variety of other non-routine laboratory tests, claimed to be prognostically important. The majority of these appear to have little practical value. Some may be considered a simple cognitive curiosity, but at least two or three components of this group may warrant further evaluation. The list of these uncommon laboratory tests includes the following determinations: a few specific serum proteins, such as prealbumin, alpha ${ }_{1}$-acid glycoprotein, beta $_{2}$-microglobulin, alpha ${ }_{1}$-antitrypsin, haptoglobin, transferrin, and ferritin; protein-bound carbohydrates; urine polyamines and modified ribonucleosides; and, finally, the angiotensin-converting enzyme. Relevant references for this category are presented in table 6 .

The iron-storage protein, ferritin, has been inconsistently shown to possess prognostic relevance. In two NSCLC studies, similar by cell type distribution and size, ferritin

Table 6. - Uncommon laboratory tests*

\begin{tabular}{|c|c|c|c|c|c|c|c|c|}
\hline & \multicolumn{4}{|c|}{ Nonsignificant $* *$} & \multicolumn{4}{|c|}{ Significant** } \\
\hline & \multicolumn{2}{|c|}{ Univariate analysis } & \multicolumn{2}{|c|}{ Multivariate analysis } & \multicolumn{2}{|c|}{ Univariate analysis } & \multicolumn{2}{|c|}{ Multivariate analysis } \\
\hline & $>200 \mathrm{pts}$ & $\leq 200 \mathrm{pts}$ & $\begin{array}{l}>200 \mathrm{pts} \\
\text { and/or } \leq 6 \\
\text { variables }\end{array}$ & $\begin{array}{c}\leq 200 \mathrm{pts} \\
\text { and }>6 \\
\text { variables }\end{array}$ & $\leq 200 \mathrm{pts}$ & $>200 \mathrm{pts}$ & $\begin{array}{c}\leq 200 \mathrm{pts} \\
\text { and/or } \leq 6 \\
\text { variables }\end{array}$ & $\begin{array}{c}>200 \mathrm{pts} \\
\text { and }>6 \\
\text { variables }\end{array}$ \\
\hline Ferritin & [70] & & [70] & [57] & [57] (130) & & & \\
\hline Transferrin & & & & & & [104] & & [104] \\
\hline $\begin{array}{l}\text { Protein-bound } \\
\text { carbohydrates }\end{array}$ & & & & & (131) & & & \\
\hline $\begin{array}{l}\text { Angiotensin-converting } \\
\text { enzyme }\end{array}$ & & & & & [132] & & & \\
\hline $\begin{array}{l}\text { Urine modified } \\
\text { ribonucleosides }\end{array}$ & & & & & (133) & & & \\
\hline Urinary polyamines & & & & & (134) & & & \\
\hline C-reactive protein & [70] & & [70] & & {$[108,114]$} & & [108] & \\
\hline Alpha $_{1}$-acid glycoprotein & & & {$[104,108]$} & & {$[108,114]$} & {$[70,104]$} & & {$[70]$} \\
\hline Beta $_{2}$-microglobulin & [70] & & {$[70]$} & & & & & \\
\hline Retinol binding protein & & & {$[70]$} & & & {$[70]$} & & \\
\hline Haptoglobin & & & [104] & & & [104] & & \\
\hline Prealbumin & {$[70]$} & & {$[70]$} & & & & & \\
\hline Alpha ${ }_{1}$-antitrypsin & & {$[65]$} & & & [135] & [104] & {$[65]$} & [104] \\
\hline
\end{tabular}

\footnotetext{
* Reference numbers in square brackets refer to studies of [NSCLC/any cell type tumours]; numbers in parentheses refer to studies of (pure SCLCs) ** according to definitions in the various studies.
} 


\begin{tabular}{|c|c|c|c|c|c|c|c|c|}
\hline & \multicolumn{4}{|c|}{ Nonsignificant** } & \multicolumn{4}{|c|}{ Significant** } \\
\hline & \multicolumn{2}{|c|}{ Univariate analysis } & \multicolumn{2}{|c|}{ Multivariate analysis } & \multicolumn{2}{|c|}{ Univariate analysis } & \multicolumn{2}{|c|}{ Multivariate analysis } \\
\hline & $>200 \mathrm{pts}$ & $\leq 200 \mathrm{pts}$ & $\begin{array}{l}>200 \mathrm{pts} \text { and/or } \\
\leq 6 \text { variables }\end{array}$ & $\begin{array}{l}\leq 200 \text { pts and } \\
>6 \text { variables }\end{array}$ & $\leq 200 \mathrm{pts}$ & $>200$ pts & $\begin{array}{l}\leq 200 \mathrm{pts} \text { and/or } \\
\leq 6 \text { variables }\end{array}$ & $\begin{array}{l}>200 \text { pts and } \\
>6 \text { variables }\end{array}$ \\
\hline Lactate dehydrogenase & {$[72]$} & & $\begin{array}{c}{[72,136]} \\
(7)\end{array}$ & $\begin{array}{c}{[137]} \\
(110,138)\end{array}$ & $\begin{array}{l}{[57,111,137,139]} \\
(7,110,118,140)\end{array}$ & $\begin{array}{c}{[51,82,136]} \\
(109,141-144)\end{array}$ & $\begin{array}{c}{[57,59,139]} \\
(121,140)\end{array}$ & $\begin{array}{r}{[51,82,145]} \\
(9,109,141-146\end{array}$ \\
\hline Albumin & [104] & & $\begin{array}{l}{[104,108]} \\
\quad(142)\end{array}$ & $\begin{array}{l}{[137]} \\
(110)\end{array}$ & $\begin{array}{c}{[90,108,114,137,147]} \\
(7,110)\end{array}$ & $(8,142)$ & $\begin{array}{l}{[59,90]} \\
(7,138)\end{array}$ & $\begin{array}{l}{[145]} \\
(8,9)\end{array}$ \\
\hline SGOT & {$[82](142,144)$} & [65] & $(142,144)$ & {$[57,65]$} & {$[57]$} & & $(138)$ & [82] (9) \\
\hline SGPT & & {$[57,65]$} & (9) & {$[57,65](138)$} & & (8) & & $(8)$ \\
\hline Alkaline phosphatase & {$[72,82]$} & (96) & $\begin{array}{c}{[72,82,136]} \\
(8,109,142,144)\end{array}$ & $\begin{array}{l}{[57,139]} \\
(96,138)\end{array}$ & {$[57,139]$} & $\begin{array}{c}{[136]} \\
(8,109,141,142,144)\end{array}$ & & $(9,141)$ \\
\hline Sodium & $(142)$ & [57] (110) & $(8,109,142)$ & [57] (96) & (96) & $(8,109,141,142,144)$ & & $(9,141)$ \\
\hline Uric acid & & [57] & & {$[57]$} & & & (138) & \\
\hline Haemoglobin & $(142,144)$ & $\begin{array}{l}{[57]} \\
(96)\end{array}$ & $\begin{array}{c}{[72,82,136]} \\
(8,9,142,144)\end{array}$ & $\begin{array}{c}{[57,59,139,148]} \\
(96,138)\end{array}$ & $\begin{array}{c}{[137,139]} \\
(7)\end{array}$ & $\begin{array}{c}{[72,82,136,149]} \\
(8)\end{array}$ & $\begin{array}{c}{[137]} \\
(7)\end{array}$ & \\
\hline Total protein & [104] & {$[57](7,96)$} & {$[104](7,9)$} & {$[57,59](96)$} & & & & \\
\hline Protein electrophoresis & & {$[65]$} & (7) & & (7) & & & \\
\hline Serum bicarbonate & & & & & & (141) & & $(9,141)$ \\
\hline Bilirubin & (144) & & $(8,144)$ & (138) & & (8) & & \\
\hline Gamma GT & & (96) & $(8,9,142)$ & [139] (96) & [139] & $(8,142)$ & & (9) \\
\hline WBC & $\begin{array}{c}{[72]} \\
(8)\end{array}$ & {$[57,65]$} & $\begin{array}{c}{[72]} \\
(8,9,109)\end{array}$ & $\begin{array}{l}{[57,139]} \\
\quad(138)\end{array}$ & [139] & $\begin{array}{c}{[52,82,149]} \\
(109,142)\end{array}$ & {$[65]$} & $\begin{array}{l}{[52,63,82]} \\
(142,145)\end{array}$ \\
\hline Calcium & {$[136](8,144)$} & & {$[72,136](8,9,144)$} & $(138)$ & & {$[72]$} & & {$[63]$} \\
\hline Platelets & $\begin{array}{c}{[72,82]} \\
(8,142,144)\end{array}$ & {$[57]$} & $\begin{array}{c}{[72,82]} \\
(8,9,142,144)\end{array}$ & $\begin{array}{c}{[57]} \\
(138)\end{array}$ & [139] & $\begin{array}{l}{[149]} \\
(109)\end{array}$ & [139] & (109) \\
\hline Urea or creatinine & {$[72]$} & {$[57]$} & {$[72]$} & {$[57]$} & & & & {$[145](9,146)$} \\
\hline ESR & (142) & {$[57]$} & {$[52,69](9,142)$} & {$[57]$} & [139] (96) & {$[52,69,149]$} & [139] (96) & \\
\hline
\end{tabular}

* Reference numbers in square brackets refer to studies of [NSCLC/any cell type tumours]; numbers in parenthesis refer to studies of (pure SCLCs) ** according to definitions in the various studies. SGOT: serum glutamic oxalacetic transaminase; SGPT: serum glutamic pyruvic transaminase; Gamma GT: gamma glutamyl transpeptidase; WBC: white blood cell; ESR: erythrocyte sedimentation rate. 
was found either an insignificant factor of prognosis (the series with more operable patients [70]), or a hardly significant one (the series with more advanced stages of disease [57]). Another SCLC study, on 39 patients only, added little, further, positive evidence [130].

Other NSCLC studies evaluated acute-phase reaction proteins, of which the most interesting are alpha ${ }_{1}$-acid glycoprotein (4 positive studies out of 4 studies), alpha $_{1-}$ antitrypsin ( 3 positive studies out of 3 ), and, less, C-reactive protein ( 2 positive studies out of 3 ).

Other laboratory tests, such as the determination of protein-bound carbohydrates, polyamines, and modified ribonucleosides, were performed in urine and sera samples from untreated patients with SCLC (maximum 41 subjects), all of which should indicate the clinical outcome [131, 133, 134].

\section{Traditional laboratory tests (table 7)}

This, and the following clinical chapter, are the largest sections both in terms of number of PFs evaluated and of relevant studies: there are scores of traditional laboratory test reports and thousands of patients studied. The simple explanation for this phenomenon is the zero cost of obtaining data. Clinical and routine laboratory tests, which are essential for therapeutic management, are available for any patient, wherever seen and treated. The only additional cost is computerized recording (already becoming widespread praxis for easier medical management) and statistical analysis. For many cooperative groups, studies of traditional PFs are the natural consequence of their clinical trials.

The list of commonly used laboratory tests evaluated as possible prognostic determinants comprises the following: serum albumin and total protein concentration; protein electrophoresis; glutamic oxalacetic and glutamic pyruvic transaminases; alkaline phosphatase and gamma glutamyl transpeptidase; lactate dehydrogenase; serum sodium, calcium, and bicarbonates; bilirubin, uric acid, creatinine, and urea serum content; erythrocyte sedimentation rate; and, finally, a number of haematological tests, such as haemoglobin concentration, or erythrocyte, leukocyte, and thrombocyte counts. Table 7 provides the appropriate references for each variable. This is undoubtedly a very "busy" table. Indeed, in order to maintain the previous scheme of presentation, studies reporting analyses of multiple laboratory tests (the majority) are cited repeatedly. In this group, both SCLC and NSCLC studies are well represented, even though, with the exception of erythrocyte sedimentation rate (ESR) and kidney function parameters, laboratory testing was reported more frequently in the former cell type.

Lactate dehydrogenase is the strongest prognostic determinant in this group, whether considered alone or in combination with other PFs. In 7 out of 8 NSCLC and in 9 out of 9 SCLC univariate tests, plus in 6 out of 9 NSCLC and in 10 out of 13 SCLC multivariate tests (for a total of 23 studies), the enzyme was found significantly or highly significantly survival-related. A further effective and independent laboratory test is the determination of serum albumin concentration (13 positive studies out of 14 studies considering either univariate or multivariate tests, and both SCLCs and NSCLCs). Equally important factors, but only when evaluated on their own, seem to be haemoglobin in NSCLC (6 significant univariate tests out of 7) and alkaline phosphatase in SCLC (5 out of 6). Other less important variables are erythrocyte sedimentation rate (4 significant univariate tests out of 5) and white blood cell count (4 out of 7) in NSCLC, as well as serum sodium concentration (6 out of 8 ) in SCLC.

However, studies are not all equally important; for example, the report of the Subcommittee for the Management of Lung Cancer (UK Coordinating Committee on Cancer Research) merits a special mention. The report, collecting information from 10 different British SCLC studies and nearly 4,000 patients, concluded that the most useful parameters, among the 17 laboratory parameters considered, were alkaline phosphatase, glutamic oxalacetic transaminase, lactate dehydrogenase, and plasma sodium [9]. In the opinion of the Subcommittee, these parameters should be evaluated in any future SCLC study [9]. In extensive-stage NSCLC, the Southwest Oncology Group experience is probably the most important [136]. The group analysed their own database, containing information on the clinical and laboratory pre-treatment characteristics of 2,531 patients, and concluded, from a subset analysis, that haemoglobin and lactate dehydrogenase were the most prognostically prominent laboratory tests, sufficiently capable of defining distinct prognostic subgroups [136].

\section{Clinical and sociodemographic characteristics (table 8)}

As previously mentioned, this is another full chapter. It deals with the following: age; sex; weight loss in the months preceding the diagnosis; performance status; stage of disease and other parameters of disease extension, such as tumour dimension, presence of metastasis in lung, brain, bone, and liver, and the number of metastatic sites; complicating lung infections; other associated disorders; plus a myriad of symptoms, physical signs, radiological findings, and other clinical observations. Table 8 is relevant to this group. Among the studies cited, a few large cooperative group reports are worth quoting. They include the Cancer and Leukemia Group B study [151], the already cited British Committee review [9], 2 South West Oncology Group reports [136, 144], and the classic Veteran's Administration Lung Group study [63].

Overloading a review on prognostic factors with a discussion on the importance of the stage of disease and performance status is clearly useless, given the unquestioned acceptance of their supremacy over any other factor believed to be effective in lung cancer [1-6]. Thus, both performance status and stage will not be further discussed, even though for the sake of completeness, they have been included in the table.

Other effective PFs in this group are weight loss in 


\begin{tabular}{|c|c|c|c|c|c|c|c|c|}
\hline & \multicolumn{4}{|c|}{ Nonsignificant** } & \multicolumn{4}{|c|}{ Significant** } \\
\hline & \multicolumn{2}{|c|}{ Univariate analysis } & \multicolumn{2}{|c|}{ Multivariate analysis } & \multicolumn{2}{|c|}{ Univariate analysis } & \multicolumn{2}{|c|}{ Multivariate analysis } \\
\hline & $>200 \mathrm{pts}$ & $\leq 200 \mathrm{pts}$ & $\begin{array}{c}>200 \mathrm{pts} \text { and } / \mathrm{or} \\
\leq 6 \text { variables }\end{array}$ & $\begin{array}{l}\leq 200 \text { pts and } \\
>6 \text { variables }\end{array}$ & $\leq 200 \mathrm{pts}$ & $>200$ pts & $\begin{array}{c}\leq 200 \mathrm{pts} \text { and/or } \\
\leq 6 \text { variables }\end{array}$ & $\begin{array}{l}>200 \text { pts and } \\
>6 \text { variables }\end{array}$ \\
\hline \multirow[t]{2}{*}{ Age } & $\begin{array}{l}{[51,52,54} \\
63,69,82]\end{array}$ & $\begin{array}{l}{[30,56-58} \\
65,90]\end{array}$ & $\begin{array}{c}{[30,51,52,54,} \\
55,61,62,68,69\end{array}$ & {$[56-58,90,148]$} & & $\begin{array}{c}{[53-55,67,68} \\
71,72,89,91,136]\end{array}$ & {$[59,65,136]$} & [152] \\
\hline & (8) & $(80,96)$ & $\begin{array}{c}72,82,89,91] \\
(8,109)\end{array}$ & (96) & $(110,150)$ & $(109,142,144)$ & $(110,150,151)$ & $(9,142,144,145)$ \\
\hline $\begin{array}{l}{[52} \\
82,\end{array}$ & $\begin{array}{l}52,53,69,72 \\
2,89,91,153] \\
(8,142)\end{array}$ & $\begin{array}{l}{[30,56} \\
57,90] \\
(96)\end{array}$ & $\begin{array}{c}{[30,52,61,62} \\
68,69,72,82,89] \\
(8,109,142)\end{array}$ & $\begin{array}{c}{[57,59,65} \\
90,148] \\
(96)\end{array}$ & $\begin{array}{l}{[58,137]} \\
(80,110)\end{array}$ & $\begin{array}{c}{[51,67,70} \\
71,136] \\
(109,144)\end{array}$ & $\begin{array}{l}{[56,58,71,91} \\
\quad 136,137] \\
\quad(48,110)\end{array}$ & $\begin{array}{c}{[51,70,145]} \\
(9,144)\end{array}$ \\
\hline Race & {$[136,154]$} & [56] $(80)$ & {$[136]$} & {$[56]$} & & (144) & & (144) \\
\hline Weight loss & {$[51,72]$} & $\begin{array}{l}{[56]} \\
(96)\end{array}$ & $\begin{array}{c}{[51,72,82,136]} \\
(116)\end{array}$ & $\begin{array}{c}{[56,139]} \\
(96)\end{array}$ & {$[57,65,137,139]$} & {$[54,55,63,69,82,136]$} & {$[57,65,137]$} & $\begin{array}{l}{[54,55,61,63} \\
69,89,104,152]\end{array}$ \\
\hline Performance status & & & $\begin{array}{c}{[108]} \\
(7)\end{array}$ & [65] & $\begin{array}{c}{[56-58,65,90,} \\
108,114,137] \\
(7,78,96,110, \\
118,150)\end{array}$ & $\begin{array}{l}{[51,52,54,55,63} \\
68,72,82,89,136] \\
\quad(8,109,141 \\
142,144)\end{array}$ & $\begin{array}{c}{[56-59,68,84} \\
90,136,137] \\
(48,96,110, \\
116,150,151)\end{array}$ & $\begin{array}{c}{[51,52,54,55,} \\
61,63,72,82, \\
89,104,145,152] \\
(8,9,109,141, \\
142,144-146)\end{array}$ \\
\hline TNM stage & & $\begin{array}{c}{[58,65]} \\
(96)\end{array}$ & & $\begin{array}{c}{[58,59,65,90]} \\
(96)\end{array}$ & $\begin{array}{l}{[5,27,56,57} \\
90,137,139]\end{array}$ & $\begin{array}{c}{[51-53,55,60} \\
66,68,70,71,73 \\
82,89,91]\end{array}$ & $\begin{array}{c}{[28,30,38,56} \\
57,62,68,84 \\
91,137,139]\end{array}$ & $\begin{array}{l}{[51,55,61,70} \\
82,89,104,145]\end{array}$ \\
\hline $\begin{array}{l}\text { ECOG stage (limited } v s \\
\text { extensive) }\end{array}$ & & & (8) & $(150)$ & $\begin{array}{l}(78,80,110 \\
118,150)\end{array}$ & $\begin{array}{l}(8,109,141 \\
142,144)\end{array}$ & $\begin{array}{l}(48,96,110, \\
116,150,151)\end{array}$ & $\begin{array}{l}(8,9,109,141 \\
142,144-146)\end{array}$ \\
\hline $\begin{array}{l}\text { Primary tumour } \\
\text { dimension }\end{array}$ & & $\begin{array}{c}{[27]} \\
(140)\end{array}$ & $\begin{array}{c}{[63]} \\
(140)\end{array}$ & {$[148]$} & & [69] & & {$[69,72]$} \\
\hline Liver metastases & {$[51]$} & (96) & {$[51,61,89](116)$} & {$[58](96,150)$} & {$[58](150,155)$} & {$[54,82,89](8)$} & (48) & {$[54,82](8)$} \\
\hline Bone metastases & & $(96,156)$ & $\begin{array}{c}{[51,61,82]} \\
(8,116,142)\end{array}$ & $\begin{array}{c}{[58]} \\
(96,138)\end{array}$ & $\begin{array}{c}{[58]} \\
(157,158)\end{array}$ & $\begin{array}{l}{[51,54,82,89]} \\
\quad(8,142)\end{array}$ & & $\begin{array}{c}{[54,89]} \\
(109,145)\end{array}$ \\
\hline Lung metastases & & & {$[61,89](8)$} & & & {$[54,89](8)$} & & [54] \\
\hline Brain metastases & {$[51]$} & {$[58]$} & {$[51,61,82,89]$} & {$[58]$} & & {$[82,89]$} & $(48)$ & {$[54,104](109,145)$} \\
\hline Number of metastases & & (96) & [136] (116) & (96) & & {$[51,136](109,144)$} & $(151)$ & {$[51,145](109,144)$} \\
\hline $\begin{array}{l}\text { Other parameters of } \\
\text { tumour extension }\end{array}$ & (142) & & {$[69,72,82]$} & {$[56,57]$} & {$[56,57]$} & $\begin{array}{c}{[54,63,69,72,} \\
82,159](109,144)\end{array}$ & & $\begin{array}{c}{[54,63,104,152]} \\
\quad(109,144)\end{array}$ \\
\hline Associated lung infection & & & & & {$[160]$} & [72] & & [72] \\
\hline Other associated illness & {$[52]$} & {$[56,57]$} & {$[52,72,89]$} & {$[56,57]$} & & {$[72,89]$} & & \\
\hline $\begin{array}{l}\text { Other (symptoms, physical } \\
\& \text { radiological signs, etc. }\end{array}$ & $1[52,82]$ & {$[57]$} & {$[52,55,72,82,89]$} & {$[57,65]$} & {$[65]$} & $\begin{array}{l}{[52,53,55,63,} \\
69,72,82,89]\end{array}$ & & $\begin{array}{c}{[63,69]} \\
(145)\end{array}$ \\
\hline
\end{tabular}

* Reference numbers in square brackets refer to studies of [NSCLC/any cell type tumours]; numbers in parenthesis refer to studies of (pure SCLCs) ** according to definitions in the various studies. TNM: tumour, node, metastasis; ECOG: eastern cooperative oncology group 


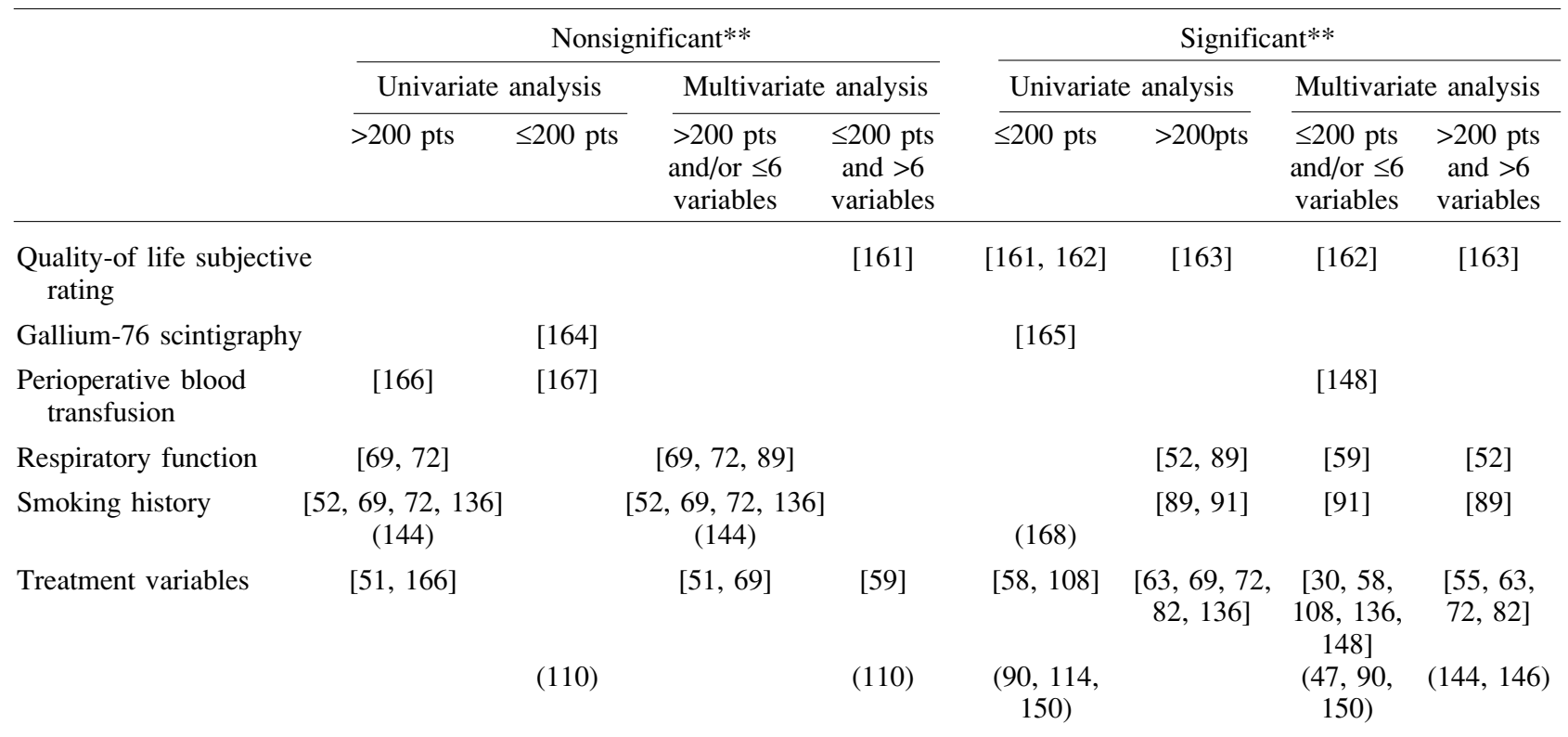

\footnotetext{
* Reference numbers in square brackets refer to studies of [NSCLC/any cell type tumours], numbers in parentheses refer to stud-
} ies of (pure SCLCs) $* *$ according to definitions in the various studies.

NSCLC, and perhaps the number of metastatic sites. Weight loss has not been sufficiently evaluated in SCLC (only 2 negative studies), while in NSCLC it does have an important prognostic impact (10 significant univariate tests out of 13, plus 11 significant multivariate tests out of 17). In both NSCLC ( 3 positive out of 3 studies considering either univariate or multivariate tests) and SCLC ( 3 out of 5), the number of metastatic sites adds a little to the stage of disease, resulting informative also in multivariate tests. To be metastatic to a particular organ or to have any other sign of more widespread tumour involvement usually worsens the prognosis, but normally has no detrimental effect when the stage of disease is already accounted for. Interestingly enough, bacterial lung infections and postoperative infections seem to have an adverse effect on survival, while the other associated diseases, considered all together, have no recognizable effect (table 8).

Both younger and older ages are inconsistently reported to be associated with unfavourable outcomes (table 8). In NSCLC, age is probably a weak factor on its own (10 positive analyses out of 22), and its value disappears completely when other variables are taken into account (only 4 positive tests out of 23). In SCLC, it may be more predictive ( 5 positive studies out of 8 studies) and independent (6 out of 9 ).

The female sex appears to be a favourable, weak (7 positive studies out of 19 studies), and marginally independent (9 out of 23) determinant in NSCLC, as well as in SCLC (a total of 6 positive studies out of 10 studies).

With one exception [144], racial differences have never been found important. In a review of male patients treated at the Veteran Administration Hospitals between 1955 and 1964 [154], not only race, but also the income status were not related to the percentage of localized disease or survival.

\section{Miscellaneous (table 9)}

In spite of the previous eight chapters, there are still a number of factors, which cannot be classified easily. They are: subjective ratings of quality of life; gallium ${ }^{67}$ uptake; perioperative blood transfusion; respiratory function testing; and smoking history. Table 9 contains the relevant references and indicates those studies, where pre-treatment factors were challenged in correlation with therapeutic variables. As already mentioned, the addition of these variables may affect the significance of the pre-treatment factors, on which this review is focused.

Except for two [144, 168], there are no SCLC studies in this group. The only factors that were sufficiently studied (such as respiratory functional testing, and smoking history) appear to be rather weak prognosticators (in all, 6 positive studies out of 14 studies), even if, in two large studies, either respiratory function or smoking habit emerged as significant variables among numerous other cofactors $[52,89]$. Other unlikely or noninfluential factors appear to be the intensity of the in vivo Gallium ${ }^{67}$ uptake and the perioperative execution of blood transfusions. The accumulation of the gallium radioisotope was measured semiquantitatively in a series of 74 diagnostic scintigraphies of NSCLC and claimed to be significantly correlated with the incidence of metastases and host survival [165]; however, a second, specifically designed study was unable to confirm the preliminary evidence [164]. Conflicting reports on the possible detrimental effect of perioperative blood transfusions [148, $166,167]$, has only had the effect of advocating new prospective studies, in spite of the recognized difficulties [169].

Perhaps, the most promising variable in this group is the patient's subjective evaluation of his own quality of 
life $[161,162]$. Self-rated instruments of recording physical and psychosocial well-being might integrate the information of performance status [162].

\section{Summary}

The best predictive results, among the many mentioned in this paper, still belong to studies based on clinical and routine laboratory data. This explains the lack of significant progress, in spite of the sophisticated mathematical analyses and the dozens of variables tested.

The myriad of known and unknown prognostic factors of lung cancer bring to mind a universe of constellations already known and constellations yet to be discovered. Like infinity, the fate of individual patients will never become a completely measurable entity. However, as the discovery of new prognostic factors proceeds, the assessment of the future of patients is becoming more reliable. Recent research has clarified the role of new constellations of PFs (e.g., biological factors); other constellations, seen indistinctly today, might be recognized as important in the future (e.g., quality of life measures); while a number of new prognostic factors (e.g., the pathological evidence of tumour neoangiogenesis or the serum content of acute-phase reaction proteins) are beginning to shine in the already known firmament. We hope that this necessarily brief and schematic overview has achieved the goal of offering an up-to-date, unbiased, and 360 degree-open picture of the entire cosmos of PFs of lung cancer.

\section{References}

1. Minna JD, Higgins GA, Glatstein EJ. Cancer of the lung. In: De Vita VT, Jr., Hellman S, Rosemberg SA, eds. Cancer. Principles and practice of oncology. Philadelphia: J.B. Lippincott Co., 1985; 507-597.

2. Lagakos SW. Prognostic factors for patients with inoperable lung cancer. In: Straus MJ, ed. Lung cancer: clinical diagnosis and treatment. New York: Grune \& Stratton, 1983; 345-353.

3. Osterlind K, Ihde DC, Ettinger DS, et al. Staging and prognostic factors in small cell carcinoma of the lung. Cancer Treat Rep 1983; 67: 3-9.

4. Stahel RA, Ginsberg R, Havemann K, et al. Staging and prognostic factors in small cell lung cancer: a consensus report. Lung Cancer 1989; 5: 119-126.

5. Feld R, Arriagada R, Ball DL, Mattson K, Sorensen JB. Prognostic factors in non-small cell lung cancer: a consensus report. Lung Cancer 1991; 7: 3-5.

6. Maki E, Feld R. Prognostic factors in patients with nonsmall cell lung cancer. A critique of the world literature. Lung Cancer 1991; 7: 27-34.

7. Cohen MH, Makuch R, Johnston-Early A, et al. Laboratory parameters as an alternative to performance status in prognostic stratification of patients with small cell lung cancer. Cancer Treat Rep 1981; 65: 187-195.

8. Vincent MD, Ashley SE, Smith IE. Prognostic factors in small cell lung cancer: a simple prognostic index is better than conventional staging. Eur J Cancer Clin Oncol 1987; 23: 1589-1599.

9. Rawson NSB, Peto J. An overview of prognostic fac- tors in small cell lung cancer. A report from the Subcommittee for the Management of Lung Cancer of the United Kingdom Coordinating Committee on Cancer Research. Br J Cancer 1990; 61: 597-604.

10. Biology of and novel therapeutic approaches for epithelial cancers of the aerodigestive tract. Proceedings of a conference held at Steamboat Springs, Colorado, April 1-7, 1991 (Monographs, J Natl Cancer Inst 1992: 13, NHI Publication No. 91-3240). Bethesda, MD: National Cancer Institute, 1992; 1-212.

11. Ciampi A, Thiffault J, Sagman U. RECPAM: a computer program for recursive partition amalgamation for censored survival data and other situations frequently occurring in biostatistics. II. Application to data on small cell carcinoma of the lung (SCLC). Comput Methods Programs Biomed 1989; 30: 283-296.

12. George SL. Identification and assessment of prognostic factors. Semin Oncol 1988; 15: 462-471.

13. Levine MN, Browman GP, Gent M, Roberts R, Goodyear M. When is a prognostic factor useful?: a guide for the perplexed. J Clin Oncol 1991; 9: 348-356.

14. Kibbellaar RE, Moolenaar KEC, Michalides RJAM, et al. Neural cell adhesion molecule expression, neuroendocrine differentiation and prognosis in lung carcinoma. Eur J Cancer 1991; 27: 431-435.

15. Graziano ST, Mazid R, Newman N, et al. The use of neuroendocrine immunoperoxidase markers to predict chemotherapy response in patients with non-small-cell lung cancer. J Clin Oncol 1989; 7: 1398-1406.

16. Kasurinen J, Syrjanen KJ. Peptide hormone immunoreactivity and prognosis in small-cell carcinoma of the lung. Respiration 1986; 49: 61-67.

17. Cline JM, Battifora $\mathrm{H}$. Abnormalities of protooncogenes in non-small cell lung cancer. Correlations with tumor type and clinical characteristics. Cancer 1987; 60: 2669-2674.

18. Slebos RJC, Kibbellaar RE, Dalesio O, et al. K-ras oncogene activation as a prognostic marker in adenocarcinoma of the lung. N Engl J Med 1990; 323: 561-565.

19. Hajj C, Akoum R, Bradley E, Paquin F, Ayoub J. DNA alterations at proto-oncogene loci and their clinical significance in operable non-small cell lung cancer. Cancer 1990; 66: 733-739.

20. Sugio K, Ishida T, Yokoyama H, Inoue T, Sugimachi $\mathrm{K}$, Sasazuki T. Ras Gene mutations as a prognostic marker in adenocarcinoma of the human lung without lymph node metastasis. Cancer Res 1992; 52: 2903 2906.

21. Kawashima K, Nomura S, Hirai H, et al. Correlation of L-myc RFLP with metastasis, prognosis and multiple cancer in lung-cancer patients. Int J Cancer 1992; 50: $557-561$.

22. Gosney JR, Field JK, Gosney MA. C-myc oncoprotein in bronchial carcinoma: expression in all major morphological types. Anticancer Res 1990; 10: 623-628.

23. Kern JA, Schwartz DA, Nordberg JE. p185 (neu) Expression in human lung adenocarcinomas predicts shortened survival. Cancer Res 1990; 56: 5184-5191.

24. Lee JS, Ro JY, Sahin A, et al. Expression of epidermal growth factor receptor (EGFR): a favorable prognostic factor for surgically resected non-small cell lung cancer (NSCLC). Proc Am Soc Clin Oncol 1989; 8: A878 (Abstract).

25. Tateishi M, Ishida T, Mitsudomi T, Sugimachi K. Prognostic implication of transforming growth factor alpha in adenocarcinoma of the lung. An immunohistochemical study. Br J Cancer 1991; 63: 130-133. 
26. Lee JS, Ro JY, Sahin AA, et al. Expression of bloodgroup antigen A. A favorable prognostic factor in nonsmall-cell lung cancer. $N$ Engl J Med 1991; 324: 1084-1090.

27. Silvestrini R, Muscolino G, Costa A, et al. Could cell kinetics be a predictor of prognosis in non-small cell lung cancer? Lung Cancer 1991; 7: 165-170.

28. Alama A, Constantini M, Repetto L, et al. Thymidine labelling index as prognostic factor in resected non-small cell lung cancer. Eur J Cancer 1990; 26: 622-625.

29. Filderman AE, Silvestri GA, Gatsonis C, Luthringer DJ, Honig J, Flynn SD. Prognostic significance of tumor proliferative fraction and DNA content in stage I nonsmall cell lung cancer. Am Rev Respir Dis 1992; 146: 707-710.

30. Zimmerman PV, Hawson GAT, Bint MH, Parsons PG. Ploidy as a prognostic determinant in surgically treated lung cancer. Lancet 1987; ii: 530-533.

31. Tirindelli-Danesi D, Teodori L, Mauro F, et al. Prognostic significance of flow cytometry in lung cancer. A 5-year study. Cancer 1987; 60: 841-851.

32. Volm M, Mattern J, Muller T, Drings P. Flow cytometry of epidermoid lung carcinomas: relationship of ploidy and cell cycle phases to survival. A five-year follow up study. Anticancer Res 1988; 8: 105-112.

33. Volm M, Hahn EW, Mattern J, Muller T, Vogt-Moykopf I, Weber E. Five-year follow-up study of independent clinical and flow cytometric prognostic factors for the survival of patients with non-small cell lung carcinoma. Cancer Res 1988; 48: 2923-2928.

34. Ten Velde GPM, Schutte B, Vermeulen A, Volovics A, Reynders MMJ, Blijham GH. Flow cytometric analysis of DNA polidy level in paraffin-embedded tissue of nonsmall-cell lung cancer. Eur J Cancer Clin Oncol 1988; 24: 455-460.

35. Volm M, Kayser K, Mattern J. Nachweis von unabhangigen zellularen prognostischen faktoren beim plattenepithelkarzinom der lunge. Strahlenther Onkol 1989; 165: 587-592.

36. Van Bodegom PC, Baak JPA, Stroet-Van Galen C, et al. The percentage of aneuploid cells is significantly correlated with survival in accurately staged patients with stage 1 resected squamous cell lung cancer and longterm follow up. Cancer 1989; 63: 143-147.

37. Gotti G, Maccherini M, Paladini P, et al. Correlazione tra sopravvivenza e fasi di ciclo cellulare. Valutazione in citometria di flusso di carcinomi polmonari epidermoidi. GIMT 1989; 43: 24-27.

38. Isobe $\mathrm{H}$, Miyamoto $\mathrm{H}$, Shimizu $\mathrm{T}$, et al. Prognostic and therapeutic significance of the flow cytometric nuclear DNA content in non-small cell lung cancer. Cancer 1990; 65: 1391-1395.

39. Ogawa J, Iwazaki M, Tsurumi T, Inoue I, Shohtsu A. Prognostic implications of DNA histogram, DNA content, and histologic changes of regional lymph nodes in patients with lung cancer. Cancer 1991; 67: 1370 1376.

40. Dazzi H, Thatcher N, Hasleton PS, Swindell R. DNA analysis by flow cytometry in nonsmall cell lung cancer: relationship to epidermal growth factor receptor, histology, tumour stage and survival. Respir Med 1990; 84: 217-223.

41. Abe S, Makimura S, Itabashi K, Nagai T, Tsuneta Y, Kawakami Y. Prognostic significance of nuclear DNA content in small cell carcinoma of the lung. Cancer 1985; 56: 2025-2030.

42. Abe S, Makimura S, Itabashi K, Kawakami Y. Nuclear
DNA content, cytomorphologic features and clinical characteristics of small cell carcinoma of the lung. Anal Quant Cytol Histol 1987; 9: 495-498.

43. Carey FA, Prasad US, Walker WS, Cameron EWJ, Lamb D, Bird CC. Prognostic significance of tumor deoxyribonucleic acid content in surgically resected small-cell carcinoma of the lung. J Thorac Cardiovasc Surg 1992; 103: 1214-1217.

44. Volm M, Drings P, Mattern J, Sonka J, Vogt-Moykopf I, Wayss K. Prognostic significance of DNA patterns and resistance-predictive tests in non-small cell lung carcinoma. Cancer 1985; 56: 1396-1403.

45. Stevenson H, Gazdar AF, Phelps R, et al. Tumor cell lines established in vitro: an independent prognostic factors for survival in non-small-cell lung cancer. Ann Intern Med 1990; 113: 764-770.

46. Masuda N, Fukuoka M, Takada M, Kudoh S, Kusunoki Y. Establishment and characterization of 20 human nonsmall cell lung cancer cell lines in a serum-free defined medium (ACL-4). Chest 1991; 100: 429-438.

47. Masuda N, Fukuoka M, Matsui K, et al. Establishment of tumor cell lines as an independent prognostic factor for survival time in patients with small cell lung cancer. J Natl Cancer Inst 1991; 83: 1743.

48. Stevenson H, Gazdar AF, Linnoila RI, et al. Lack of relationship between in vitro tumor cell growth and prognosis in extensive-stage small-cell lung cancer. $J$ Clin Oncol 1989; 7: 923-931.

49. Merkel DE, Dressler LG, McGuire WL. Flow cytometry, cellular DNA content, and prognosis in human malignancy. J Clin Oncol 1987; 5: 1690-1703.

50. World Health Organization. Histologic typing of lung tumours. Am J Clin Pathol 1982; 77: 123-136.

51. O'Connell JP, Kris MG, Gralla RJ, et al. Frequency and prognostic importance of pretreatment clinical characteristics in patients with advanced non-small-cell lung cancer treated with combination chemotherapy. J Clin Oncol 1986; 4: 1604-1614.

52. Benichou J, Fabre $\mathrm{Ch}$, Chastang $\mathrm{Cl}$, et al. Facteurs prognostiques du cancer du poumon opéré non à petites cellules: etude à partir d'un essai thérapeutique randomisé. Rev Mal Respir 1987; 4: 301-309.

53. Coy PC, Elwood JM, Coldman AJ. Clinical indicators of prognosis in unresected-lung cancer. Chest 1981; 80: $453-458$.

54. Lanzotti VJ, Thomas DR, Boyle LE, Smith TL, Gehan EA, Samuels ML. Survival with inoperable lung cancer: an integration of prognostic variables based on simple clinical criteria. Cancer 1977; 39: 303-313.

55. Pater JL, Loeb M. Nonanatomic prognostic factors in carcinoma of the lung. Cancer 1982; 50: 326-331.

56. Bonomi $\mathrm{P}$, Gale $\mathrm{M}$, Rowland $\mathrm{K}$, et al. Pre-treatment prognostic factors in stage III non-small cell lung cancer patients receiving combined modality treatment. Int J Radiat Oncol Biol Phys 1991; 20: 247-252.

57. Ferrigno D, Buccheri GF. A comprehensive evaluation of serum ferritin levels in lung cancer patients. Lung Cancer 1992; 8: 85-94.

58. Sakurai M, Shinkai T, Eguchi K, et al. Prognostic factors in non-small cell lung cancer: multiregression analysis in National Cancer Center Hospital (Japan). Cancer Res Clin Oncol 1987; 113: 563-566.

59. Muraki M, Toda Y, Haragushi R, Sugihara R, Kubo H, Nakajima S. Study of prognostic factors of survival in patients with unresectable non-small cell lung cancer. Gan To Kagaku Ryoho 1991; 18: 585-592.

60. Naruke T, Kondo H, Goya T, Tsuchiya R, Suemasu K. 
Prognostic factors in lung cancer. Gan To Kagaku Ryoho 1988; 15: 2179-2185.

61. Buccheri GF, Ferrigno D. Prognostic value of the tissue polyptide antigen in lung cancer. Chest 1992; 101: 1287-1292.

62. Fraire AE, Roggli VL, Vollmer RT, et al. Lung cancer heterogeneity. Prognostic implications. Cancer 1987; 60: 370-375

63. Stanley KE. Prognostic factors for survival in patients with inoperable lung cancer. J Natl Cancer Inst 1980; 65: 25-32.

64. Wilde J, Haenselt V, Luft D. The impact of histological type and tumour localisation on the prognosis in 1,000 resected lung cancer patients with special view to adenocarcinoma. Pneumologie 1990; 44: 1287-1293.

65. Walop W, Chrétien M, Colman NC, et al. The use of biomarkers in the prediction of survival in patients with pulmonary carcinoma. Cancer 1990; 65: 2033-2046.

66. Kayser K, Bulzebruck H, Probst G, Vogt-Moykopf I. Retrospective and prospective tumor staging evaluating prognostic factors in operated bronchus carcinoma patients. Cancer 1987; 59: 355-361.

67. Rossing TH, Rossing RG. Survival in lung cancer. An analysis of the effects of age, sex, resectability, and histopathologic type. Am Rev Respir Dis 1982; 126: 771-777.

68. Capewell S, Sudlow MF. Performance and prognosis in patients with lung cancer. Thorax 1990; 45: 951-956.

69. Clee MD, Hockings NF, Johnston RN. Bronchial carcinoma: factors influencing postoperative survival. Br J Dis Chest 1984; 78: 225-235.

70. Muller T, Marshall RJ, Cooper EH, Watson DA, Walker DA, Mearns AJ. The role of serum tumour markers to aid the selection of lung cancer patients for surgery and the assessment of prognosis. Eur J Cancer Clin Oncol 1985; 21: 1461-1466.

71. Ferguson MK, Skosey C, Hoffman PC, Golomb HM. Sex-associated differences in presentation and survival in patients with lung cancer. J Clin Oncol 1990; 8: 1402-1407.

72. Gail MH, Eagan RT, Feld R, et al. Prognostic factors in patients with resected stage I non-small cell lung cancer. A report from the Lung Cancer Study Group. Cancer 1984; 54: 1802-1813.

73. Mountain CF, Lukeman JM, Hammar SP, et al. The relationship of disease extent and cell type to survival in a clinical trials population. J Surg Oncol 1987; 35: 147-156.

74. Takamori S, Noguchi M, Morinaga S, et al. Clinicopathologic characteristics of adenosquamous carcinoma of the lung. Cancer 1991; 67: 649-654.

75. Mangum MD, Greco FA, Hainsworth JD, Hande KR, Johnson DH. Combined small-cell and non-small-cell lung cancer. J Clin Oncol 1989; 7: 607-612.

76. Bepler G, Neumann K, Holle R, Havemann K, Kalbfleisch $\mathrm{H}$. Clinical relevance of histologic subtyping in small cell lung cancer. Cancer 1989; 64: 74-79.

77. Aisner SC, Finkelstein DM, Ettinger DS, Abeloff MD, Ruckdeschel JC, Eggleston JC. The clinical significance of variant-morphology small-cell carcinoma of the lung. J Clin Oncol 1990; 8: 402-408.

78. Strauchen JM, Egbert B, Kosek JC, Mackintosh R, Misfeldt DS. Morphologic and clinical determinants of response to therapy in small cell carcinoma of the lung. Cancer 1983; 52: 1088-1092.

79. Sehested M, Hirsch FR, Osterlind K, Olsen JE. Morphologic variations of small cell lung cancer. A histopathologic study of pretreatment and posttreatment specimens in 104 patients. Cancer 1986; 57: 804-807.

80. Fraire AE, Johnson EH, Yesner R, Zhang XB, Spjut HI, Greenberg SD. Prognostic significance of histopathologically subtype and stage in small cell lung cancer. Hum Pathol 1992; 23: 520-528.

81. Hirsch FR, Osterlind K, Hansen HH. The prognostic significance of histopathologic subtyping of small cell carcinoma of the lung according to the classification of the World Health Organization. Cancer 1983; 52: 2144-2150.

82. Sorensen JB, Badsberg JH, Olsen J. Prognostic factors in inoperable adenocarcinoma of the lung: a multivariate regression analysis of 259 patients. Cancer Res 1989; 49: 5748-5754.

83. Sorensen JB, Hirsch FR, Olsen J. The prognostic implication of histopathologic subtyping of pulmonary adenocarcinoma according to the classification of the World Health Organization. An analysis of 259 consecutive patients with advanced disease. Cancer 1988; 62: 361-367.

84. Sorensen JB, Badsberg JH. Prognostic factors in resected stages I and II adenocarcinoma of the lung. A multivariate regression analysis of 137 consecutive patients. Thorac Cardiovasc Surg 1990; 99: 218-226.

85. Albain KS, True LD, Golomb HM, Hoffman PC, Little AG. Large cell carcinoma of the lung. Ultrastructural differentiation and clinicopathologic correlations. Cancer 1985; 56: 1618-1623.

86. Clayton F. Bronchioloalveolar carcinomas. Cell types, patterns of growth, and prognostic correlates. Cancer 1986; 57: 1555-1564.

87. Lee T, Horner RD, Silverman JF, Chen Y, Jenny C, Scarantino CW. Morphometric and morphologic evaluations in stage III non-small cell lung cancers. Prognostic significance of quantitative assessment of infiltrating lymphoid cells. Cancer 1989; 63: 309-316.

88. Macchiarini P, Fontanini G, Hardin MJ, Squartini F, Angeletti CA. Relation of neovascularisation to metastasis of non-small-cell lung cancer. Lancet 1992; 340: 145-146.

89. Buccheri G, Ferrigno D, Vola F. Carcinoembryonic antigen (CEA), tissue polyptide antigen (TPA), and other prognostic indicators in the squamous cell carcinoma of the lung. Lung Cancer 1993; 10: 21-33.

90. Kanda T, Soda H, Tanigushi T, et al. Prognostic factors in nonresected adenocarcinoma of the lung. Gan No Rinsho 1987; 33: 1259-1265.

91. Sobue T, Suzuki T, Fujimoto I, Doi O, Tateishi R, Sato T. Prognostic factors for surgically treated lung adenocarcinoma patients, with special reference to smoking habit. Jpn J Cancer Res 1991; 82: 33-39.

92. Hirsch FR, Matthews MJ, Aisner S, et al. Histopathologic classification of small cell lung cancer. Changing concepts and terminology. Cancer 1988; 62: 973-977.

93. Folkman J. What is the evidence that tumors are angiogenesis dependent? J Natl Cancer Inst 1990; 82: 4-6.

94. List AF, Hainsworth JD, Devis BV, Hande KR, Greco FA, Johnson DH. The syndrome of inappropriate secretion of antidiuretic hormone (SIADH) in small-cell lung cancer. J Clin Oncol 1986; 4: 1191-1198.

95. De La Monte SM, Hutchins GM, Moore GW. Paraneoplastic syndromes and costitutional symptoms in prediction of metastatic behavior of small cell carcinoma of the lung. Am J Med 1984; 77: 851-857.

96. Riggi M, Brunet ML, Ruffie P, et al. Univariate and multivariate analysis on prognostic factors in extended small cell lung cancer (SCLC). In: Second International 
Conference on Small Cell Lung Cancer. Milano Marittima (Ravenna), Italy, May 11-12, 1990.

97. Dimopoulos MA, Fernandez JF, Samaan NA, Holoye PY, Vassilopoulou-Sellin R. Paraneoplastic Cushing's syndrome as an adverse prognostic factor in patients who die early with small cell lung cancer. Cancer 1992; 69: 66-71.

98. Sgarella A, Vitulio P, Tomaselli S, Cremaschi P, Guazzotti M, Nascimbene C. Stato immunitario e sopravvivenza in 50 pazienti con carcinoma epidermoidale broncogeno sottoposti ad intervento chirurgico. Rassegna di Patologia dell'Apparato Respiratorio 1990; 5: 39-43.

99. Johnston-Early A, Cohen MH, Fossieck BE Jr, et al. Delayed hypersensitivity skin testing as a prognostic indicator in patients with small cell lung cancer. Cancer 1983; 52: 1395-1400.

100. Lissoni P, Barni S, Rovelli F, Tancini G. Lower survival in metastatic cancer patients with reduced interleukin-2 blood concentration. Oncology 1991; 48: 125-127.

101. Buccheri GF, Marino P, Preatoni A, Ferrigno D, Moroni GA. Soluble interleukin 2 receptor in lung cancer. An indirect marker of tumor activity? Chest 1991; 99: 1433-1437.

102. Uchida A, Kariya Y, Okamoto N, Sugie K, Fujimoto T, Yagita M. Prediction of postoperative clinical course by autologous tumor-killing activity in lung cancer patients. J Natl Cancer Inst 1990; 82: 1697-1701.

103. Benson MD, Eyanson S, Fineberg NS. Serum amyloid A in carcinoma of the lung. Cancer 1986; 57: 1783-1787.

104. Buccheri GF, Ferrigno D. Serum proteins and lung cancer prognosis. Chest 1993; 104: 1195.

105. Ferrigno D, Buccheri G, Biggi A. Serum tumour markers in lung cancer: history, biology and clinical applications. Eur Respir J 1994; 7: 186-197.

106. Buccheri GF, Ferrigno D, Sartoris AM, Violante B, Vola $\mathrm{F}$, Curcio A. Tumor markers in bronchogenic carcinoma: superiority of tissue polyptide antigen to carcinoembryonic antigen and carbohydrate antigenic determinant 19-9. Cancer 1987; 60: 42-50.

107. Ferrigno D, Buccheri GF, Cecchini C, Marchetti G. Clinical value of a multiple biomarker assay (CEA, TPA, NSE) in patients with SCLC. GIMT 1990; 44: 135-140.

108. Marshall RJ, Curzon PDG, Pearson SB, Cooper EH, Muers MF, Peake MD. Prognosis in squamous cell lung cancer: the contribution of plasma proteins. Tumor Diagn Ther 1985; 6: 195-198.

109. Sagman U, Maki E, Evans WK, et al. Small-cell carcinoma of the lung: derivation of a prognostic staging system. J Clin Oncol 1991; 9: 1639-1649.

110. Gronowitz JS, Bergstrom R, Nou E, et al. Clinical and serologic markers of stage and prognosis in small cell lung cancer. Cancer 1990; 66: 722-732.

111. Buccheri GF, Violante B, Sartoris AM, Ferrigno D, Curcio A, Vola F. Clinical value of a multiple biomarker assay in patients with bronchogenic carcinoma. Cancer 1986; 57: 2389-2396.

112. Dent PB, McCulloch PB, Wesley-James O, MacLaren R, Muirhead W, Dunnet CW. Measurements of carcinoembryonic antigen in patients with bronchogenic carcinoma. Cancer 1978; 42: 1484-1491.

113. Concannon JP, Dalbow MH, Hodgson SE, et al. Prognostic value of preoperative carcinoembryonic antigen (CEA) plasma levels in patients with bronchogenic carcinoma. Cancer 1978; 42: 1477-1483.

114. Marshall RJ, Curzon PDG, Pearson SB. Prognosis in squamous cell lung cancer: the contribution of plasma proteins. Tumor Diagn Ther 1985; 6: 195-198.
115. Jaques G, Bepler G, Holle R, et al. Prognostic value of pretreatment carcinoembryonic antigen, neuron-specific enolase, and creatine kinase-BB levels in sera of patients with small cell lung cancer. Cancer 1988; 62: 125-134.

116. Laberge F, Fritsche HA, Umsawasdi T, et al. Use of carcinoembryonic antigen in small cell lung cancer. Prognostic value and relation to the clinical course 1 . Cancer 1987; 59: 2047-2052.

117. Sculier JP, Feld R, Evans WK, et al. Carcinoembryonic antigen: a useful prognostic marker in small-cell lung cancer. J Clin Oncol 1985; 3: 1349-1354.

118. Gronowitz JS, Steinholtz L, Kallander CFR, Hagberg H, Bergh J. Serum deoxythymidine kinase in small cell lung carcinoma of the lung. Cancer 1986; 58: 111-118.

119. Body JJ, Sculier JP, Raymakers N, et al. Evaluation of squamous cell carcinoma antigen as a new marker for lung cancer. Cancer 1990; 65: 1552-1556.

120. Vincent RG, Chu TM, Fergen TB, Ostrander M. Carcinoembryonic antigen in 228 patients with carcinoma of the lung. Cancer 1975; 36: 2069-2076.

121. Van der Gaast A, Van Putten WL, Oosterom R, Cozijnsen M, Hoekstra R, Splinter TAW. Prognostic value of serum thymidine kinase, tissue polypetide antigen and neuron specific enolase in patients with small cell lung cancer. Br J Cancer 1991; 64: 369-372.

122. Jorgensen LG, Hirsch FR, Skov BG, Osterlind K, Cooper $\mathrm{EH}$, Larsson LI. Occurrence of neuron specific enolase in tumour tissue and serum in small cell lung cancer. $\mathrm{Br}$ J Cancer 1991; 63: 151-153.

123. Harding M, McAllister J, Hulks G, et al. Neurone specific enolase (NSE) in small cell lung cancer a tumour marker of prognostic significance? Br J Cancer 1990; 61: 605-607.

124. Jorgensen LG, Osterlind K, Hansen HH, Cooper EH. The prognostic influence of serum neuron specific enolase in small cell lung cancer. Br J Cancer 1988; 58: 805-807.

125. Szturmowicz M, Roginska E, Roszkowski K, Kwiek S, Filipecki S, Rowinska-Zakrzewska E. Prognostic value of neuron-specific enolase in small cell lung cancer. Lung Cancer 1993; 8: 259-264.

126. Buccheri GF, Ferrigno D. Usefulness of tissue polypeptide antigen in staging monitoring, and prognosis of lung cancer. Chest 1988; 93: 565-569.

127. Ebert W, Leichtweis B, Bulzebruck H, Drings P. The role of IMx SCC assays in the detection and prognosis of primary squamous-cell carcinoma of the lung. Diagn Oncol 1992; 2: 203-210.

128. Diez M, Cerdan FJ, Ortega MD, Torres A, Picardo A, Balibrea JL. Evaluation of serum CA 125 as a tumor marker in non-small cell lung cancer. Cancer 1991; 67: $150-154$

129. Kimura Y, Fujii T, Hamamoto K, et al. Serum CA125 level is a good prognostic indicator in lung cancer. $\mathrm{Br}$ J Cancer 1990; 62: 676-678.

130. Cox R, Gyde OH, Leyland MJ. Serum ferritin levels in small cell lung cancer. Eur J Cancer Clin Oncol 1986; 22: 831-835.

131. Waalkes TP, Abeloff MD, Ettinger DS, Woo KB, Kuo $\mathrm{KC}$, Gehrke CW. Serum protein-bound carbohydrates and small cell carcinoma of the lung. Correlation with extent of disease, tumor burden, survival, and clinical response categories. Cancer 1983; 52: 131-139.

132. Roulston JE, Galloway PJ, Douglas GJ. Plasma angiotensin-converting enzyme activity in patients with bronchial carcinoma. Br J Dis Chest 1986; 80: 229-234.

133. Waalkes TP, Abeloff MD, Ettinger DS, et al. Modified 
ribonucleosides as biological markers for patients with small cell carcinoma of the lung. Eur J Cancer Clin Oncol 1982; 18: 1267-1274.

134. Woo KB, Waalkes TP, Abeloff MD, Lenhard RE Jr, Gehrke CW, Kuo KC. Urinary polyamines for evaluating the course of disease for patients with small cell carcinoma of the lung. Cancer 1983; 52: 1684-1690.

135. Higashiyama M, Doi O, Kodama K, Yokouchi H, Tateishi R. An evaluation of the prognostic significance of alpha ${ }_{1}-$ antitrypsin expression in adenocarcinomas of the lung: an immunohistochemical analysis. Br J Cancer 1992; 65 : 300-302.

136. Albain KS, Crowley JJ, LeBlanc M, Livingston RB. Survival determinants in extensive-stage non-small-cell lung cancer: the Southwest Oncology Group Experience. J Clin Oncol 1991; 9: 1618-1626.

137. Takifuji N, Fukuoka M, Negoro S, et al. Prognostic factors affecting survival and response in patients with advanced non-small cell lung cancer treated with combination chemotherapy. Gan To Kagaku Ryoho 1990; 17: 429-434.

138. Tritz DB, Doll DC, Ringerberg QS, et al. Bone marrow involvement in small cell lung cancer. Clinical significance and correlation with routine laboratory variables. Cancer 1989; 63: 763-766.

139. Engan T, Hannisdal E. Blood analyses as prognostic factors in primary lung cancer. Acta Oncol 1990; 29: 151-154.

140. Hainsworth JD, Johnson DH, Farese RV, Macey JW, Vaughn WK, Greco FA. Limited stage small cell lung cancer: analysis of clinical prognostic factors. South Med $J$ 1987; 80: 1518-1522.

141. Cerney T, Blair V, Anderson H, Bramwell V, Thatcher N. Pretreatment prognostic factors and scoring system in 407 small-cell lung cancer patients. Int J Cancer 1987; 39: 146-149.

142. Allan SG, Stewart ME, Love S, Combleet MA, Smyth JF, Leonard RCF. Prognosis at presentation of small cell carcinoma of the lung. Eur J Cancer 1990; 26: 703-705.

143. Sagman U, Feld R, Evans WK, et al. The prognostic significance of pretreatment serum lactate dehydrogenase in patients with small-cell lung cancer. Clin Oncol 1991; 9: 954-961.

144. Albain KS, Crowley JJ, LeBlanc M, Livingston RB. Determinants of improved outcome in small-cell lung cancer: an analysis of the 2,580-patient Southwest Oncology Group data base. J Clin Oncol 1990; 8: 1563-1574.

145. Urata A. Prognostic factors in unresectable lung cancer. Gan To Kagaku Ryoho 1988; 15: 2035-2042.

146. Niederle N, Eberhardt W, Hirche H. Pratherapeutische prognostische factoren beim kleinzelligen bronchialkarzinom. Onkologie 1988; 11 (Suppl. 2): 34-40.

147. Fatzinger P, DeMeester TR, Darakjian H, Iascone C, Golomb HM, Little AG. The use of serum albumin for further classification of stage III non-oat cell lung cancer and its therapeutic implications. Ann Thorac Surg 1984; 37: 115-122.

148. Tartter Pl, Burrows L, Kirschner P. Perioperative blood transfusion adversely affects prognosis after resection of stage I (subset N0) non-oat cell lung cancer. J Thorac Cardiovasc Surg 1984; 88: 659-662.

149. Gislason T, Nou E. Sedimentation rate, leukocytes, platelet count and haemoglobin in bronchial carcinoma: an epidemiological study. Eur J Respir Dis 1985; 60: 141-146.

150. Shinkai T, Sakurai M, Eguchi K, et al. Prognostic factors in small cell lung cancer: multivariate analysis in the National Cancer Center Hospital. Jpn J Clin Oncol 1989; 19: 135-141.

151. Spiegelman D, Maurer LH, Ware JH, et al. Prognostic factors in small-cell carcinoma of the lung: an analysis of 1,521 patients. J Clin Oncol 1989; 7: 344-354.

152. Green N, Kurohara SS, George WF. Cancer of the lung, an in-depth analysis of prognostic factors. Cancer 1971; 28: 1229-1233.

153. Katz HR. Prediction of survival in lung cancer. $N$ Engl J Med 1992; 327: 1597 (Letter).

154. Page WF, Kuntz AJ. Racial and socioeconomic factors in cancer survival. A comparison of veterans administration results with selected studies. Cancer 1980; 45: 1029-1040.

155. Mulshine JL, Makuch RW, Johnston-Early A, et al. Diagnosis and significance of liver metastases in small cell carcinoma of the lung. J Clin Oncol 1984; 2: 733-741.

156. Kelley BW, Morris JF, Harwood BP, Bruya TE. Methods and prognostic value of bone marrow examination in small cell carcinoma of the lung. Cancer 1984; 53: 99-102.

157. Clamon GH, Edwards WR, Hamous JE, Scupham RK. Patterns of bone marrow involvement with small cell lung cancer. Cancer 1984; 54: 100-102.

158. Bezwoda WR, Lewis D, Livini N. Bone marrow involvement in anaplastic small cell lung cancer. Diagnosis, hematologic features, and prognostic implications. Cancer 1986; 58: 1762-1765.

159. Kondo H, Naruke T, Tsuchiya R, et al. Pleural lavage cytology immediately after thoracotomy as a prognostic factor for patients with lung cancer. Jpn J Cancer Res 1989; 80: 233-237.

160. Perlin E, Bang KM, Shah A, et al. The impact of pulmonary infections on the survival of lung cancer patients. Cancer 1990; 66: 593-596.

161. Buccheri GF, Ferrigno D, Brunelli C, Tamburini M. Survival correlates of ratings of psychophysical wellbeing in lung cancer. Chest 1993; 104: 455 (Abstract).

162. Kaasa S, Mastekaasa A, Lund E. Prognostic factors for patients with inoperable non-small cell lung cancer, limited disease. The importance of patients' subjective experience of disease and psychosocial well-being. Radiother Oncol 1989; 15: 235-242.

163. Ruckdeschel JC, Piantadosi S. Assessment of quality of life (QL) by the functional living index-cancer (FLIC) is superior to performance status for prediction of survival in patients with lung cancer. Proc Am Soc Clin Oncol 1989; 8: A1209(Abstract).

164. Buccheri GF, Vola F, Ferrigno D, Curcio A, Violante B. Lack of clinical significance of Gallium-67 uptake in non-small cell lung cancer. Eur J Respir Dis 1987; 71: 356-361.

165. Higashi T, Nakamura K, Suzuki S, Allison JR, Wakao $\mathrm{H}$. Ga-67 scan as a prognostic indicator in primary lung carcinoma. Clin Nucl Med 1982; 7: 553-557.

166. Pastorino U, Valente M, Cataldo I, Lequaglie C, Ravasi G. Perioperative blood transfusion and prognosis of resected stage I lung cancer. Eur J Cancer Clin Oncol 1986; 22: 1375-1378.

167. Pena CM, Rice TW, Ahmad M, Medendorp SV. Significance of perioperative blood transfusions in patients undergoing resection of stage I and II non-small-cell lung cancers. Chest 1992; 102: 84-88.

168. Johnston-Early A, Cohen MH, Minna JD, et al. Smoking abstinence and small cell lung cancer survival: an association. J Amer Med Assoc 1980; 244: 2175-2179.

169. Piantadosi S. The adverse effect of blood transfusion in lung cancer. Chest 1992; 102: 6-8. 